\title{
"SUBSTANTIAL EVIDENCE" IN ADMINISTRATIVE LAW
}

\section{E. Blythe Stason $†$}

Lying ahead of every quasi-judicial decision of an administrative tribunal is the possibility of judicial review. Actually judicial review is involved in only a small percentage of cases, but occasionally error rears its head and the courts stand ready within the scope of their authority to check injustice from abuse of administrative power.

One of the most important questions arising in connection with judicial review of administrative decisions concerns the scope thereof, that is, the extent to which decisions will be probed by the courts and reversed if found erroneous. A major subdivision of the subject of scope of review involves the meaning of the term "substantial evidence", today so frequently met in legislation in some such provision as "the findings of fact by the Commission shall, if supported by substantial evidence, be conclusive." The purpose of this article is, first, to discuss the growing significance of the term "substantial evidence" in contemporary administrative procedure and, second, to probe the meaning of the term.

\section{Statutory Provisions Involving the "Substantial. EVIDENCE" RULE}

Before entering upon the principal inquiry, it is desirable to examine the relevant statutory provisions. The term "substantial evidence" has had a considerable history in American statute law. It first appeared in federal administrative legislation in the Federal Trade Commission Act of I9I4, although it appeared there in modified form. That Act as now amended provides in Section 5 (c) that "any person, partnership, or corporation required by an order of the Commission to cease and desist from using any method of competition or act or practice may obtain a review of such order in the Circuit Court of Appeals of the United States . . . by filing . . . a written petition. . . The Commission forthwith shall certify and file in the court a transcript of the entire record in the proceedings. . . . The findings of the Commission as to the facts, if supported by evidence, shall be conclusive." 1

$\dagger$ A. B., I9I3, University of Wisconsin; S. B., I9I6, Massachusetts Institute of Technology; J. D., I922, University of Michigan Law School; Dean, University of Michigan Law School; author of Cases and MATzRIALS ON ADMINISTRATIVE TRIBUNALS (1937) and numerous articles in legal periodicals.

I. 38 STAT. 7 Ig (19I4), 15 U. S. C. A. \$ 45 (c) (1927), as amended 52 STAT. I028 (1938), I5 U. S. C. A. \& 45 (c) (Supp. 1940). The original Act used the word "testimony" instead of the word "evidence", but the two terms can seemingly be treated as synonymous. 
Although the word "evidence" is not preceded by the adjective "substantial", nevertheless the courts read in the word by interpretation. ${ }^{2}$ Consequently, the findings of the Federal Trade Commission as to the facts, if supported by "substantial evidence", are conclusive.

Not only the Trade Commission Act but also some eighteen other federal statutes have set up the substantial evidence standard for judicial review of fact decisions of the administrative agencies in charge. One of these statutes, namely the Clayton Act, ${ }^{8}$ was enacted in I9I4 as a companion measure to the Trade Commission Act. Section I I of the Act contains provisions for enforcement by various agencies, and it is stipulated that "the findings of the Commission or the Board as to the facts, if supported by testimony, shall be conclusive." This is also the language of the original Trade Commission Act, and it no doubt should be construed to establish the substantial evidence rule in cases falling within its purview. In I922 the Tariff Commission Act was adopted using the word "evidence". " In I930 two statutes were placed on the books making use of the rule, namely an amendment of the Federal Radio Act of 1927, now the Federal Communications Act, ${ }^{5}$ and the Federal Power Commission Act. ${ }^{8}$ Thereafter the term became virtually standard drafting practice. In I933 it appeared in the Securities Act. ${ }^{7}$ In 1934 it was used in the Securities Exchange Act. ${ }^{8}$ In 1935 it

2. Consolidated Edison Co. v. National Labor Relations Board, 305 U. S. 197, 229 (1938), in which case the court disposes of doubt concerning the matter by saying, "We agree that the statute, in providing that "the findings of the Board as to the facts if supported by evidence, shall be conclusive', means supported by substantial evidence." See also Washington, V. \& M. Coach Co. v. National Labor Relations Board, 30I U. S. 142,147 (1936).

3. Clayton Act "The findings of the commission, authority or board as to the facts, if supported by testimony, shall be conclusive. . " 38 STAT. 734 (I9r4), I5 U. S. C. A. \&21 (I927), as amended 52 STAT. 1028 (I938), I5 U. S. C. A. \$27 (Supp. 1940).

4. Tariff Commission Act. [Findings on charges of unfair practices in import trade.] "Such findings, if supported by evidence, shall be conclusive, except that a rehearing may be granted by the commission and except that . . . an appeal may be taken from said findings upon a question or questions of law only to the U. S. Court of Customs and Patent Appeals. . " 46 STAT. 703 (I930), I9 U. S. C. A. \& I337 (c) (1937).

5. Federal Communications Commission Act. The Act provides that appeal may be taken in certain cases to the Court of Appeals of the District of Columbia and contains a proviso, "That the review by the court shall be limited to questions of law and that findings of fact by the Commission, if supported by substantial evidence, shall be conclusive unless it shall clearly appear that the findings of the Commission are arbitrary or capricious. - :" 48 STAT. rog4 (r934), 47 U. S. C. A. \$ 402 (e) (Supp. 1940), derived from the amendment to the Federal Radio Commission Act of 1927,46 STAT. 844 (I930).

6. Federal Power Commission Act. "The finding of the Commission as to the facts, if supported by substantial evidence, shall be conclusive. . . " 49 STAT. 860 (I935), I6 U. S. C. A. \$ 8251 (b) (I94I), added to Act of 1920, 4 I STAT. I063 (I920). 7. Securities Act of 1933. "The finding of the Commission as to the facts, if supported by evidence, shall be conclusive. . . 48 STAT. 80 (1933), 15 U. S. C. A. $\$ 77$ (i) (a) (Supp. 1940).

8. Securities Exchange Act of 1934. "The findings of the Commission as to the facts, if supported by substantial evidence, shall be conclusive. . . ." 48 STAT. 901 (1934), I5 U. S. C. A. \$ 78 (y) (a) (Supp. 1940). 
appeared in the Public Utility Holding Company Act, ${ }^{9}$ in the Alcohol Administration legislation, ${ }^{10}$ in the Toll Bridge Act, ${ }^{11}$ in the Social Security Act, ${ }^{12}$ and in the National Labor Relations Act. ${ }^{13}$ In 1937 it was set forth in the Bituminous Coal Act; ${ }^{14}$ in 1938 it found its way into the Fair Labor Standards Act, ${ }^{15}$ the Agricultural Adjustment Act, ${ }^{16}$ the Natural Gas Act, ${ }^{17}$ the Food and Drug Act, ${ }^{18}$ and the Civil Aeronautics Authority Act; ${ }^{19}$ and finally in 1940 it was used in the Bridge Alteration Act. ${ }^{20}$ As appears from the excerpts printed in the footnotes, in twelve of these acts the words "substantial evidence" are used. In the other enactments, the qualifying adjective is omitted, but, as has already been indicated, the meaning is seemingly no different. In each of these important statutory structures, then, the decisions of the administrative tribunals charged with enforcement are accorded conclusiveness on the facts if the decisions are supported by substantial evidence. It is apparent that the term has become one of wide application and great significance. ${ }^{21}$ The primary purpose of the present

9. Public Utility Holding Co. Act of 1935. "The findings of the Commission as to the facts, if supported by substantial evidence, shall be conclusive. . . " 49 STAT. 834 (1935), 15 U. S. C. A. $\$ 79$ (x) (Supp. 1940).

Io. Federal Alcohol Administration Act. "The finding of the Administrator as to the facts, if supported by substantial evidence, shall be conclusive. . . " 49 STAT. 978 (I935), 27 U. S. C. A. \& 204 (h) (Supp. I940).

II. Toll Bridge Act. "The review by such courts shall be limited to questions of law, and the findings of fact by the Secretary of War, if supported by substantial evidence, shall be conclusive. - ." 49 STAT. 67I, 33 U. S. C. A. \$ 505 (Supp. I940).

12. Social Security Act. [The original Social Security Act contained no provision concerning the scope of review. However, by amendment in 1939 the following sentence was included.] "The findings of the Board as to any fact, if supported by substantial evidence, shall be conclusive. - " 49 STAT. 624 (I935), 42 U. S. C. A. $\$ 405$ (g) (Supp. I940), as amended, 53 STAT. I368 (I939).

13. National Labor Relations Act. "The findings of the Board as to the facts, if supported by evidence, shall be conclusive. . ." 49 STAT. 453 (I935), 29 U. S. C. A. § I60 (e) (Supp. I940).

I4. Bituminous Coal Act. "The findings of the Commission as to the facts, if supported by substantial evidence, shall be conclusive. . . " 50 STAT. 85 (I937), I5 U. S. C. A. $\$ 836$ (b) and (c) (1939).

I5. Fair Labor Standards Act of 1938. "The review by the court shall be limited to questions of law, and findings of fact by the Administrator when supported by substantial evidence shall be conclusive. - ." 52 STAT. ro24 (r938), 49 U. S. C. A. $\S 646$ (e) (Supp. 1940).

16. Agricultural Adjustment Act of I938. "The review by the court shall be limited to questions of law, and the findings of fact by the review committee, if supported by evidence, shall be conclusive. . ." 52 STAT. 63 (1938), 7 U. S. C. A. \$ I366 (I939).

17. Natural Gas Act. "The finding of the Commission as to the facts, if supported by substantial evidence, shall be conclusive. - ." 52 STAT. 83I (I938), I5 U. S. C. A. § 7I7T (b) (I939).

18. Food, Drug and Cosmetic Act. "The findings of the Secretary as to the facts, if supported by substantial evidence, shall be conclusive. . . " 52 STAT. I055 (1938), 2I U. S. C. A. § 37I (f) (3) (Supp. 1940).

19. Civil Aeronautics Act. "The findings of fact by the Authority, if supported by substantial evidence, shall be conclusive. - ." 52 STAT. 1024 (I938), 49 U. S. C. A. $\$ 646$ (e) (Supp. r940).

20. Bridge Alteration Act. "The review by the court shall be limited to questions of law, and the findings of fact by the Secretary, if supported by substantial evidence, shall be conclusive. . " 54 STAT. 50I (I940), 33 U. S. C. A. \$ 520 (Supp. I940).

2I. The term has been used very little in state statute law. For a careful survey of state provisions, see Dickinson, The Conclusiveness of Administrative Fact Determination Since the Ben Avon Case (1935) I6 P. U. Forr. 30-42. 
inquiry is to appraise the importance of the substantial evidence rule and then to determine the meaning that should be ascribed to the words in application to the numerous cases which arise.

\section{Importance of the "Substantial Evidence" Rule}

Before embarking upon the inquiry into the meaning of the rule, it will prove worthwhile to explore its significance by pausing for a somewhat more penetrating view of the area of its application and its manner of functioning as a part of the administrative process. There are several reasons for assigning substantial significance to the rule.

In the first place, broadly speaking, it marks a substantial portion of the boundary line between two supposedly coordinate branches of government. It determines the extent to which the judiciary is under an obligation to serve as a check upon erroneous action by the administrative branch of government. Commenting upon the rule, Judge Hamilton, of the Sixth Circuit Court of Appeals, has well said that "the rule of substantial evidence is one of fundamental importance and is the dividing line between law and arbitrary power." 22 Stated somewhat more specifically, although less picturesquely, the phrase stands as the primary indication of legislative intent with respect to the extent of the courts' power to review determinations of fact of administrative cognizance. Expressed in terms of governmental science, in a political scheme grounded upon the wisdom of checks and balances to prevent usurpation and arbitrary exercise of power by any one of the three branches of government, judicial review of administrative decisions constitutes a vital and essential feature of the total plan, and the substantial evidence rule stands as a rather considerable fraction of judicial review.

In the second place, although in the formative years of administrative law the courts paid a minimum of attention to statutory stipulations concerning the scope of judicial review, the substantial evidence rule is today gradually being accepted by the courts as a controlling guide. In the earlier years administrative law was evolved in large part by the federal courts under the Interstate Commerce Act. However, that Act fails to prescribe a meaningful standard of judicial review, and the courts were left no alternative but to evolve their own standards. Under the Hepburn Amendment of I906, except for reparations orders which are expressly declared to be only "prima facie" correct, the Act was silent upon the question of scope of review. The only pertinent provision was contained in a little-used enforcement sec-

22. National Labor Relations Board v. Thompson Products, Inc., 97 F. (2d) ${ }^{\circ}$ I3, 15 (C. C. A. 6th, 1938). 
tion worded in the following curiously inadequate manner: "If, after hearing, the court determines that the order was regularly made and duly served, and that the carrier was in disobedience of the same, the court shall enforce obedience to such order by a writ of injunction or other process . . . ."23 Both in cases brought under this provision, and in cases involving an attempt to secure an injunction to prevent the enforcement of the Commission's orders, the courts were forced to evolve their own standards of judicial review of facts. This has no doubt contributed to the judicial habit of hand-tailoring the standards of other statutes as well.

However, now that nineteen administrative acts contain the substantial evidence rule in express form, the courts, with the phraseology governing the scope of review thus more clearly set forth, have been relying, to an increasing extent, upon the specific statutory words as a guide. ${ }^{24}$ This is entirely as it should be, since, laying aside for the moment the so-called constitutional or jurisdictional facts, there are few limitations upon the power of the legislature to determine the boundary line between administrative conclusiveness and judicial review of fact questions. ${ }^{25}$ The legislative mandate should prevail and the courts should endeavor to comply with it. For this very reason, then, there is a good deal to be said for determining, with all possible accuracy, the meaning attributed by the Congress to the words "substantial evidence".

In the third place, the sheer number and importance of cases adjudicated by administrative agencies are great and are ever becoming greater; and the very bulk of the task performed by contemporary administrative tribunals constitutes a reason for closer scrutiny of the standards of judicial review. Not all of the agencies involved in the statutes which have been cited carry heavy case loads; but some of them, at least, decide large numbers of cases involving interests of great magnitude and issues which affect every man, woman, and child in the land. To mention a few examples, the Federal Trade Commission during the fiscal year $1937^{-1938}$ issued some 246 cease and desist orders, about 200 of which involved decisions by the Commission in contested cases; the Securities and Exchange Commission during the

23. Interstate Commerce Act, 43 STAт. 633, 49 U. S. C. A. § I6 (I I2) (I929).

24. For example, see National Labor Relations Board v. Bradford Dyeing Ass'n, 310 U. S. 318 (I940); National Labor Relations Board v. Waterman Steamship Corp., 309 U. S. 206 (I940); National Labor Relations Board v. Wallace Manufacturing Co., 95 F. (2d) 818 (1938).

25. Fong Yue Ting v. United States, I49 U. S. 698 (1893); Murray's Lessee v. Hoboken Land and Improvement Co., 18 How. 272, 284 (U. S. 1855). Of course, matters of legislative or administrative policy may not be subjected to review by "constitutional courts". Federal Radio Commission v. General Electric Company, 28I U. S. 464 (1930). 
fiscal year 1938-I939 entered a total of 361 formal opinions, I5 under the Securities Act, 46 under the Securities Exchange Act, and 300 under the Public Utility Holding Company Act; the National Labor Relations Board in the same fiscal year rendered 893 formal decisions, $5^{12}$ in representation cases and $38 \mathrm{I}$ in unfair labor practice cases; and in the same year the Federal Communications Commission rendered formal decisions in upwards of 200 radio application cases. ${ }^{26}$ Moreover, in the majority of these cases the principal issues are questions of fact falling within the purview of the substantial evidence rule. Of course, not all of the cases reach the courts in judicial review proceedings. In fact, only a small percentage of them is appealed. However, judicial review is a potentiality in all cases; and even though no appeal is taken the standards prescribed by statute for review are indirectly important both by reason of the pressure they exert upon the administrative proceedings themselves and also because of their bearing upon the desirability of seeking a judicial reconsideration of any particular administrative decision. As a consequence, on the ground of mere number of cases and sweep of the issues involved, the standards of judicial review, including the substantial evidence rule, loom large in significance.

In the fourth place, we must recognize that the importance of the scope of review of facts under the substantial evidence rule is greater today than ever before because of an increasing content ascribed to the term "fact question". We must take into account an important modification that is being made in our doctrines of constitutional interpretation, which bids fair to throw into the category of fact questions subject to the substantial evidence rule the questions which have hitherto been singled out as "constitutional facts" and accorded special treatment and full review.

A few words of elaboration are necessary. In I920, in Ohio Valley Water Company v. Ben Avon Borough, ${ }^{27}$ a public utility rate case arising under the Public Utility Act of the State of Pennsylvania, the United States Supreme Court held (Justices Brandeis, Holmes, and Clarke dissenting) that due process of law required that fact issues with constitutional content (in this case confiscation under a rate schedule) be accorded an opportunity for independent judicial review. A subsequent decision, St. Joseph Stockyards Co. v. United States, ${ }^{28}$ (Justices Brandeis, Stone, and Cardozo dissenting) applied the same principle to a federal administrative rate order, with a slight modifica-

26. The figures are taken from the Final Report of the Attorney General's Committee on Administrative Procedure, Appendix F (194I) 314-326.

27. 253 U. S. 287 ( 1920 ).

28. 298 U. S. 38,53 (1936). 
tion. ${ }^{29}$ In each case a vigorous dissenting opinion recorded a disapproval of according broad review on the question of confiscation. Today, however, certain signs point toward an early adoption of the dissenting views, with the result that so-called constitutional facts are possibly destined to be denied special treatment in the future. It is likely that they will be treated just as are the common variety of fact issues and subjected to the substantial evidence rule whenever the statute prescribes that standard of judicial review..$^{30}$

A recent United States Supreme Court decision will illustrate the point and support the assertion. On June I3, I940, the United States Supreme Court decided the case of Railroad Commission of Texas $v$. Rowan \& Nichols Oil Co. ${ }^{31}$ The court there held in a six to three decision that, even though confiscation and a denial of due process were alleged by the company, the courts had no power to review the fact issues underlying the administrative order. The case involved the constitutionality under the Fourteenth Amendment of an oil proration order based upon hourly potential flow. The order reduced the oil company's permissible flow from 22,000 barrels per day to 22 barrels per day. The company claimed that the order was entered in complete disregard of the estimated recoverable oil lying under its land, and therefore it contended that the order resulted in a violation of constitutional rights. The lower federal court set aside the order on the ground of want of due process of law. The Supreme Court reversed the lower court, holding that the lower court had exceeded its powers of judicial

29. The Court, Mr. Justice Hughes writing the opinion, indicated that the constitutional requirement of an independent opportunity for judicial review of the due process issue did not mean that the decision of the administrative agency would necessarily be given no weight whatsoever by the court. On this point he said, "But this judicial duty to exercise an independent judgment does not require or justify disregard of the weight which may properly attach to findings upon hearing and evidence. On the contrary, the judicial duty is performed in the light of the proceedings already had and may be greatly facilitated by the assembling and analysis of the facts in the course of the legislative determination. Judicial judgment may be none the less appropriately independent because informed and aided by the sifting procedure of an expert legislative agency. Moreover, as the question is whether the legislative action has passed beyond the lowest limit of the permitted zone of reasonableness into the forbidden reaches of confiscation, judicial scrutiny must of necessity take into account the entire legislative process, including the reasoning and findings upon which the legislative action rests. We have said that in a question of ratemaking there is a strong presumption in favor of the conclusions reached by an experienced administrative body after a full hearing'. Darnell v. Edwards, 244 U. S. 564, 569. The established principle which guides the court in the exercise of its judgment on the entire case is that the complaining party carries the burden of making a convincing showing and that the court will not interfere with the exercise of the rate-making power unless confiscation

30. A like conclusion has been even more positively expressed in Landis, THE ADMINISTRATINE PROCESS (1938) I4I, and in a very recent article by James Hart, Judicial Review of Administrative Action: $A$ Thesis (I94I) 9 GEo. WASH. L. REv. 499,503 .

3I. 3ro U. S. 573 (I940). A second decision in another branch of the same case appears in Railway Commission of Texas v. Rowan \& Nichols Oil Co., 6I Sup. Ct. 343
(I94I). 
review. Mr. Justice Frankfurter, writing the opinion of the majority of the court, said:

"A controversy like this always calls for fresh reminder that courts must not substitute their notions of expediency and fairness for those which have guided the agencies to whom the formulation and execution of policy have been entrusted . . .

But whether a system of proration based upon hourly potential is as fair as one based upon estimated recoverable reserves or some other factor or combination of factors is in itself a question for administrative and not judicial judgment. . . . Certainly in a domain of knowledge still shifting and growing and in a field where judgment is therefore necessarily beset by the necessity of inferences bordering on conjecture, even for those learned in the art, it would be presumptuous for the courts, on the basis of conflicting expert testimony, to deem the view of the administrative tribunal acting under legislative authority offensive to the Fourteenth Amendment." 32

Although the particular decision may perhaps be differentiated from the utility rate determinations involved in the Ohio Valley Water Company and St. Joseph Stockyards cases on the ground that the order, an oil proration order, involved a high degree of technical expertness and administrative judgment and discretion, nevertheless the tenor of the opinion is such as to presage the overruling or the strict limiting of the decisions in the earlier cases. It is therefore, perhaps, not being too precipitate to anticipate the acceptance of the views of the dissenting opinions in those cases and to conclude that in the future fact issues involving due process, equal protection, and doubtless also other constitutional guaranties may no longer be entitled to an independent court review as a matter of constitutional right. Regardless of the merits of this change of doctrine, the significant point for present purposes is that in the future constitutional fact questions are very likely to fall under the substantial evidence rule instead of being accorded full judicial review. Since, in general, cases involving these issues deal with exceedingly important interests including both economic values and civil rights, and since they often raise questions of high emotional or political content, the significance of the substantial evidence rule and of the precise meaning to be read into it becomes very much greater than has been the case hitherto.

Finally, for still one more reason is the meaning of the substantial evidence rule likely to prove of greater importance in the future than it has in the past. In years gone by the courts have been inclined to

32. 310 U. S. $573,580-581$ (1940). 
regard certain issues as questions of law although they might well have been treated as questions of fact. As questions of law, they have necessarily fallen outside the range of the substantial evidence rule. This has been particularly. true of certain cases involving interpretation of statutory terms where the borderline between fact and law is often diffcult to discern. ${ }^{33}$ The point may be illustrated by reference to the early cases arising under the Federal Trade Commission Act. For example, in Federal Trade Commission v. Gratz, ${ }^{34}$ the first case to reach the Supreme Court under the Act, the court held, in effect, that in passing upon cases arising under the statutory phrase "unfair methods of competition" the application of that phrase to a particular fact situation must be deemed a question of interpretation of law, and that the question as to whether or not a given trade practice should be deemed to fall within or without the phrase should be subject to full judicial review. The substantial evidence rule had no application.

Somewhat more recently, however, notably in Federal Trade Commission v. Keppel and Bros., ${ }^{35}$ the Supreme Court, Mr. Justice Stone speaking, although reasserting the proposition that unfair methods of competition were to be defined and determined by the courts, went on to say:

“. . . in passing on that question, the determination of the Commission is of weight. It was created with the avowed purpose of lodging the administrative functions committed to it in a body specially competent to deal with them by reason of information, experience, and careful study of the business and economic conditions of the industry affected, and it was organized in such a manner, with respect to the length and expiration of the terms of office of its members, as would give to them an opportunity to acquire the expertness in dealing with these special questions concerning industry that comes from experience. . . . If the point were more doubtful than we think it is, we should hesitate to reject the conclusion of the Commission, based as it is upon clear, specific, and comprehensive findings supported by evidence." 36

In other words, the language of the court points toward a more liberal recognition of the Commission's work than has been accorded in the past, and it seems to mean that many of the questions that have hitherto been treated as questions of statutory interpretation (and hence questions of law to be given plenary judicial review) will in the future

33. Observe Dickinson's classic statement, "Matters of law grow downward into roots of fact, and matters of fact reach upward, without a break, into matters of law. The knife of policy alone effects an artificial cleavage, at the point where the court chooses to draw the line between public interest and private right." Dickinson, ADMINISTRATIVE JUSTICE AND THE SUPREMACY OF LAW (I927) 55.

34. 253 U. S. 42 I (I920).

35. 29 I U. S. 304 (1934).

36. Id. at 3I4. 
be treated as questions of fact. So regarded, they will fall within the scope of the substantial evidence rule and be subject to judicial reversal only if Commission findings are not supported by substantial evidence.

For all of these reasons, then, we may properly conclude that the substantial evidence rule is of genuine and increasing importance and that its meaning is well worth probing. The rule involves a fundamental question of polity on a broad front; the courts are beginning to rely upon it in formulating the scope of judicial review; the cases involved are numerous and far-reaching; the questions covered by the rule include not only the conventional questions of fact but also those mixed creations, questions of constitutional and jurisdictional right; and, finally, many borderline questions of interpretation seem likely to fall within its scope.

\section{Possible Meanings of the Term "Substantial Evidence"}

We come now to the task of determining the meaning of "substantial evidence". Unfortunately, the term does not lend itself to expression by a simple formula. "A word is not a crystal, transparent and unchanging; it is the skin of a living thought and may vary greatly in color and content according to the circumstances and the time in which it is used." 37 "Substantial evidence" is one of those numerous legal terms of doubtful content which may mean almost anything, but which for the sake of reasonable certainty in administration of justice should be given as definite and certain a content as possible. The law is full of such terms. "Fraud", "the reasonable man", "reasonable rates", "negligence"-all are terms commonly met in legal parlance; all are terms that have broad and indefinite dictionary meanings; but all have acquired definiteness of content by long continued legal usage. The demand for reasonable certainty in the law is thus satisfied. So also the term "substantial evidence" should be given a content sufficiently definite and precise so that courts, administrative agencies, and litigants may understand its meaning and apply it with a modicum of intelligence to the variant situations that arise.

Controlling, as it does, the extent of the courts' power to examine and reverse fact decisions of administrative agencies, the term might conceivably mean several different things ranging all the way from a bare minimum of evidence being regarded as sufficient to sustain a decision to a virtual requirement that the decision be supported by a preponderance of the testimony. Indeed, judicial authority is not wanting for a wide variety of possibilities falling between these two extremes.

37. Mr. Justice Holmes in Towne v. Eisner, 245 U, S. 418 (I918). 
Construed grammatically, the term might conceivably, though not reasonably, mean something just merely beyond the limits of the mere "scintilla" of evidence formerly regarded as sufficient to block a motion for a directed verdict. Under such a definition, the requirement would simply call for a searching of the record to find some relevant testimony to support the order, ignoring all countervailing testimony introduced by the opposing party. This construction, however, would virtually preclude judicial reversal of fact decisions even though grossly erroneous; and, although such closely restricted review may be warranted in some areas of administrative action, ${ }^{38}$ it can scarcely be justified in many of the fields to which the substantial evidence rule is applied. It is worth noting that the scintilla rule has now been universally abandoned in connection with direction of verdicts in jury trials. ${ }^{39}$

Again, and construed somewhat less restrictively, substantial evidence may be related to the term "arbitrary and capricious action" in such manner as to permit setting aside decisions only if found to be arbitrary. Indeed, this view seems to be rather frequently adopted by the courts. ${ }^{40}$

38. Both state and federal statutes occasionally prescribe the narrowest possible review of fact determination. In state statute law. that practice is particularly noticeable in the workmen's compensation legislation. For an excellent analysis of state statute law in this regard see Dickinson, The Conclusiveness of Fact Determination Since the Ben Avon Case (1935) I6 P. U. ForT. 30-447.

In federal legislation also there are several examples of strictly limited review, or review limited to questions of law. For example, the Board of Tax Appeals Act provides, "The Circuit Courts of Appeals . $\cdot$ shall have exclusive jurisdiction to review the decisions of the Board. . . ( (c) Upon such review, such courts shall have power to affirm, or, if the decision of the Board is not in accordance with law, to modify or reverse the decision of the Board, with or without remanding the case for a rehearing, as justice may require." 44 STAT. IIO (Ig26), 26 U. S. C. A. § 64 I (c) (I) (I935).

Also in the Longshoremen's and Harbor Workers' Compensation Act it is provided as follows: "If not in accordance with law, a compensation order may be suspended or set aside in whole or in part, through injunction proceedings, ${ }^{*} \cdot \dot{S}^{-}$brought by any party in interest . . in the Federal district court. . ." 44 STAT. I436 (I927), 33 U. S. C. A. $\$ 921$ (b) (Supp. I940).

The Veterans' Administration enjoys the highest degree of conclusiveness possible to confer. The Act provides, "All decisions rendered by the Administrator of Veterans" Affairs under the provisions of sections 701 to 721 of this title, or the regulations issued pursuant thereto, shall be final and conclusive on all questions of law and fact, and no other official or court of the United States shall have jurisdiction to review by mandamus or otherwise any such decision." 48 STAT. 9 (I933), 38 U. S. C. A. §705 (Supp. I940).

39. The scintilla rule was seemingly abandoned in the federal courts in $187 \mathrm{x}$ : See Improvement Company v. Munson, I4 Wall. 442,448 (U. S. I87I), in which the court said, "Nor are judges any longer required to submit a question to a jury merely because some evidence has been introduced by the party having the burden of proof, unless the evidence be of such a character that it would warrant the jury in finding a verdict in favor of that party."

The English courts formerly applied the scintilla rule but have long since abandoned it. Ryder v. Wombwell, L. R. 4 Ex. 32 (1868); Metropólitan Ry. v. Jackson, 3 App. Cas. I93 (1877); Dublin, W. \& W. Ry. v. Slattery, 3 App. Cas. II55 (I878).

For a well-reasoned Iowa case showing the shift in view in state practice see Meyer v. Houck, 85 Iowa 319,52 N. W. 235 (I892).

40. See, e. g., Denver Union Stockyard Co.v. United States, 304 U. S. 470 (I938); Federal Radio Commission v. Nelson Bros. Bond \& Mortgage Co., 289 U. S. 266 (I933) ; American Sumatra Tobacco Corp. v. S. E. C., Iro F. (2d) II7 (App. D. C. 1940); Farley v. Heininger, I05 F. (2d) 79 (App. D. C. 1939); Farley v. Simmons, 
At the other extreme, the term "substantial evidence" may, if one is willing to strain sufficiently, be construed to require a weighing of the testimony, a balancing of the persuasive effect of the evidence on the one side of the material issues against that on the other. ${ }^{41}$ If this interpretation should be adopted, no evidence would be deemed "substantial" unless, upon an examination of the whole record, substantial conviction of the "rightness" of the decision should exist in the mind of the reviewing court. This construction would be fully as objectionable as the scintilla rule. It would make of the court a final arbiter on the issues of fact in all cases. If generally adopted, it would not only overload the courts, but, still worse, it would withdraw from the administrative tribunal "appointed by law and informed by experience" the conclusiveness which common sense and good administration demand. ${ }^{42}$

99 F. (2d) 343 (App. D. C. I938) ; Atlanta Beer Distributing Co., Inc. v. Alexander, 93 F. (2d) II (C. C. A. 5th, I937); Inghram v. Union Stockyards Co., 64 F. (2d) 390 (C. C. A. 8th, 1933).

41. In the volume entitled Governmant Administration: Essays IN HoNOR of FrANK J. GoonNow, the chapter on Judicial Review of the Finding and Awards of Industrial Accident Commissions, by Charles Groves Haines, at 127-173, shows how far courts can go. Particular reference is made to state court decisions construing the provisions of state statutes designed to provide a strictly limited judicial review.

Certain federal cases in which substantial evidence seems to mean virtually weighing the evidence are Federal Trade Commission v. Curtis Publishing Co., 260 U. S. 568 (I923); Federal Trade Commission v. Gratz, 253 U. S. 421 (I920); National Labor Relations Board v. Thompson Products Inc., 97 F. (2d) 13 (C. C. A. 6th, 1938).

42. Of course, there are areas of administrative law in which a broad power of judicial review is desirable and even necessary. The legislature can always confer broad powers upon the courts in such cases. In many instances it has done so by express statutory provision. The following excerpts from federal statutes illustrate the point:

Interstate Commerce Commission. “(2) If a carrier does not comply with ain order for the payment of money within the time limit in such order, the complainant, or any person for whose benefit such order was made, may file. . . a petition setting forth briefly the causes for which he claims damages, and the order of the commission in the premises. Such suit in the district court of the United States shall proceed in all respects like other civil suits for damages, except that on the trial of such suit the findings and order of the commission shall be prima facie evidence of the facts therein stated. . . " 34 STAT. 590 (I906), 49 U. S.
C. A. \& I6, I 2 (I929).

Department of Agriculture (Packers and Stockyards Act-Stockyards). "The findings and orders of the Secretary shall be prima facie evidence of the facts therein stated. $\because 42$ STAT. I65 (I92I), 7 U. S. C. A. \$ 210 (f) (I939).

Department of Agriculture (Commodity Exchange Act). [Designation of any board of trade as a "contract market" may be suspended or revoked, after notice and hearing. Appeal may be taken to the C. C. A., which may affirm or set aside the order or order it to be modified.] "No such order of the said commission shall be modified or set aside by the circuit court of appeals unless it is shown by the issued without due notice and a reasonable opportunity having been afforded to such board of trade for a hearing, or infringes the Constitution of the United States,

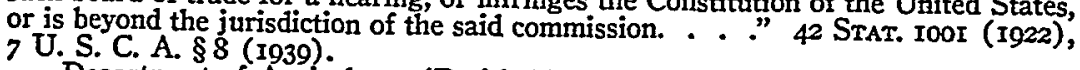

Department of Agriculture (Perishable Agricultural Commodities Act). "(c) Either party adversely affected by the entry of a reparation order by the Secretary may - appeal therefrom to the district court of the United States. - . Such suit in the district court shall be a trial de novo of the United States. - except that the findings of fact and order or orders of the Secretary shall be prima facie evidence of the facts therein stated. . . . 48 STAT. 587 (I930), 7 U. S. C. A. \& 4999 (c)
(I939). 
There are, however, any number of intermediate positions between the extremes above stated..$^{43}$ One of these intermediate positions I should like to state with some accuracy, for I shall endeavor to establish the proposition that it is the most acceptable meaning to ascribe to the term. It is this: the term "substantial evidence" should be construed to confer finality upon an administrative decision on the facts when, upon an examination of the entire record, the evidence, including the inferences therefrom, is found to be such that a reasonable man, acting reasonably, might have reached the decision; but, on the other hand, if a reasonable man, acting reasonably, could not have reached the decision from the evidence and its inferences then the decision is not supported by substantial evidence and it should be set aside. In effect, this is the prevailing rule in jury trials relative to the direction of verdicts, and is also the prevailing rule applied by appellate courts in setting aside jury verdicts because contrary to the evidence. Parenthetically it may be observed that the appellate courts' power to reverse a trial court and order a new trial is generally much narrower than the

Department of Labor (The Walsh-Healy Act). The Secretary of Labor ". . . shail make findings of fact after notice and hearing, which findings shall be conclusive upon all agencies of the United States, and if supported by the preponderance of the evidence, shall be conclusive in any court of the United States. . . 49 STat. 2038 (1936), 4 I U. S. C. A. \$39 (Supp. 1940). But cf. Perkins v. Lukens Steel Co., 310 U. S. II3 (1940), which precludes judicial review of at least some types of decisions of the Secretary under the Walsh-Healy Act. lows:

43. The cases taking an intermediate position may be roughly classified as fol-

(a) Cases in which no more than a bare minimum of evidence seems required to sustain the administrative decision. Swayne and Hoyt, Ltd. v. United States, 300 U. S. 297 (1937) ; Booth S. S. Co. v. United States, 29 F. Supp. 22I (S. D. N. Y. I939), also possibly National Labor Relations Board v. Bradford Dyeing Asso., 3ro U. S. 3I8 (1940), and National Labor Relations Board v. Waterman Steamship Corp., 309 U. S. 206 (1940).

(b) Cases in which less than substantial evidence is equated to arbitrary action. Denver Union Stockyard Co. v. United States, 304 U. S. 470 (1937); Federal Radio Commission v. Nelson Bros. Co., 289 U. S. 266 (I933); American Sumatra Tobacco Corp. v. S. E. C., I Io F. (2d) II7 (App. D. C. I940) ; Farley v. Heininger, I05 F. (2d) 79 (App. D. C. 1939); Farley v. Simmons, 99 F. (2d) 343 (App. D. C. I938) ; Atlanta Beer Distributing Co., Inc. v. Alexander, 93 F. (2d) II (C. C. A. 5th, 1937) ; Inghram v. Union Stockyard Co. of Omaha, 64 F. (2d) 390 (C. C. A. 8th, 1933).

(c) Cases in which "substantial evidence" is equated to the directed verdict rule in jury trial. National Labor Relations Board v. Columbian Enameling and Stamping Co., 306 U. S. 292 (1939); Consolidated Edison Co. v. National Labor Relations Board, 305 U. S. 197 (I938); Magnolia Petroleum Co. v. National Labor Relations Board, I12 F. (2d) 545 (C. C. A. 5th, 1940) ; National Labor Relations Board v. Goshen Rubber and Mfg. Co., IIo F. (2d) 432 (C. C. A. 7th, 1940); National Labor Relations Board v. Sterling Electric Motors, Inc., Iog F. (2d) Ig4 (C. C. A. 9th, I940); National Labor Relations Board v. Asheville Hosiery Co., I08 F. (2d) 288 (C. C. A. 4th, 1939); National Labor Relations Board v. Bell Oil and Gas Co., 98 F. (2d) 406 (C. C. A. 5th, r938); National Labor Relations Board v. Wallace Mff. Co., 95 F. (2d) 8i8 (C. C. A. 4th, I938); Appalachian Electric Power Co. v. National Labor Relations Board, 93 F. (2d) 985 (C. C. A. 4th, 1938).

(d) Cases in which substantial evidence is found to exist if the court believes there is "a rational basis" for the decision. Rochester Tel. Corp. v. United States, 307 U. S. 125 (I939); Mississippi Valley Barge Co. v. United States, 292 U. S. 282 (1934); Montana Power Co. v. Federal Power Commission, II2 F. (2d) 371 (C. C. A. 9th, 1940) : Yankee Network, Inc. v. Federal Communications Commission, I07 F. (2d) 212 (Ảpp. D. C. I939). 
corresponding power of the trial court. The trial court has discretionary power to set aside any verdict which is contrary to the evidence, but it is under the legal duty to do so when the verdict is so contrary to the evidence that no reasonable jury acting reasonably could have reached the conclusion. Failure to perform this duty is reversible error in the appellate court. Where mention is made in this article of the rules applicable to setting aside jury verdicts reference is made to the rules guiding appellate courts. ${ }^{44}$

From the foregoing brief analysis, it becomes apparent that the term "substantial evidence" can be construed in a variety of ways without too great a strain on the imagination and that it is, in fact, construed variously by the courts. The question now confronting us is which construction should be adopted.

\section{The Meaning Intended by Congress for the Term "Substantial Evidence"}

In view of the fact that the phrase "substantial evidence" is a term used in statutes and a term which is far from clear and unambiguous in meaning, we are entitled, in endeavoring to interpret it, to consider not only the grammatical construction of the words themselves, which in this case would prove rather sterile, but also certain extrinsic matters. We may examine the background of judicial experience which must have been present in the minds of the members of Congress, and also those features of the legislative histories of the statutes in question relevant to the matter at hand. These considerations will prove more fruitful.

First, let us glance at judicial experience. Judicial opinions written in cases reviewing decisions of the Interstate Commerce Commission under the original act of I887 furnished certain of the earliest ideas concerning the proper meaning and scope of judicial review. The Act stipulated that the "reports" of the Commission should be deemed "prima facie evidence of the matters therein stated." 45 Even though

44. For decisions in law actions setting forth the rules concerning directed verdicts and setting aside verdicts, see Begert v. Payne, 274 Fed. 784 (C. C. A. 6th, 1921); Bartalott v. International Bank, II9 Ill. 259, 9 N. E. 898 (I887); Farmers Bank v. Duvall, 7 Gill \& J. 78 (Md. I835); Ferguson v. Tucker, 2 Harris \& J. I82 (Md. I828); Rich v. Rich, I6 Wend. 663 (N. Y. I837). Although the language in different opinions varies, and there are different practices in different states (see Sunderland, Directing a Verdict for the Party Having the Burden of Proof (I9I3) II MICH. L. REV. I98), it is generally accepted under modern rules that a verdict may be directed, even though there is some conflict in testimony, if the testimony so heavily preponderates one way that a verdict the other way would necessarily have to be set aside as so contrary to the evidence that no reasonable jury acting reasonably could have reached it. A distinction must, however, be drawn between the power of the trial court in its discretion to set aside a verdict because "contrary to the evidence", and the duty to set aside a grossly erroneous verdict-a duty the breach of which is reversible error. See Begert v. Payne, supra, for a careful appreciation of this distinction.

45. 24 StaT. 384-385 (r887), 47 U. S. C. A. \$§ 13-16a (I928). 
this provision might have been regarded as leaving the door open to full review, the courts declined to weigh the evidence and refused to attempt a balancing of the persuasiveness of the testimony on the one side against the testimony of the other.

As early as 1896, for example, in Cincinnati etc. Railway Co. $v$. Interstate Commerce Commission, ${ }^{46}$ the court was using language which indicated that it had no intention of "weighing" the testimony. Justice Shiras, speaking for the court on the subject of judicial review, said :

"It has been forcibly argued that in the present case the Commission did not give due weight to the facts that tended to show that the circumstances and conditions were so dissimilar as to justify the rates charged; but the question was one of fact peculiarly within the province of the Commission whose conclusions have been accepted and approved by the Circuit Court of Appeals, and we find nothing in the record to make it our duty to draw a different conclusion." 47

Under the original Interstate Commerce Act, however, the powers of the Commission were so sharply restricted by judicial interpretation that the questions which reached the courts for consideration were relatively few and unimportant, and the proper standards to be applied in reviewing decisions of the Commission on questions of fact were not fully and clearly developed.

In I 906 the so-called Hepburn Amendment was adopted, and the standards of judicial review as expressed in the Act were substantially changed. Only as to reparations orders was the former prima facie evidence rule retained. As to other cases the rule was abolished. No provision whatsoever was made in the Act for judicial review. In this state of the statute law, judicial review of Commission decisions other than money awards usually took the form of injunction proceedings to restrain the enforcement of Commission orders; and since there was no controlling language in the statute concerning the scope of review in such proceedings, the courts, of necessity, worked out their own rules of action. The two leading cases on the subject are Interstate Commerce Commission v. Illinois Central ${ }^{48}$ and Interstate Commerce Commission v. The Union Pacific Railroad. ${ }^{49}$ In the latter case, $\mathrm{Mr}$. Justice Lamar, who delivered the opinion of the court, wrote:

46. $x 62$ U. S. $184(1896)$.

47. Later Supreme Court decisions under the original Interstate Commerce Act serve to confirm the court's willingness to follow the commission decisions on fact questions when within the limits of reason. For a good discussion of these cases see Tollefson, Judicial Review of the Decisions of the Interstate Commerce Commission (1938) 5 GEO. WASH. L. REV. 503.

48. 215 U. S. 452 (I9I0).

49. 222 U. S. 541 (I9II). 
"There has been no attempt to make an exhaustive statement of the principle involved, but in cases thus far decided, it has been settled that the orders of the Commission are final unless (I) beyond the power which it could constitutionally exercise; or (2) beyond its statutory power; or (3) based upon a mistake of law. But questions of fact may be involved in the determination of questions of law, so that an order, regular on its face, may be set aside if it appears that (4) the rate is so low as to be confiscatory and in violation of the constitutional prohibition against taking property without due process of law; or (5) if the Commission acted so arbitrarily and unjustly as to fix rates contrary to evidence, or without evidence to support it; or (6) if the authority therein involved has been exercised in such an unreasonable manner as to cause it to be within the elementary rule that the substance and not the shadow, determines the validity of the exercise of the power. . .

"In determining these mixed questions of law and fact, the court confines itself to the ultimate question as to whether the Commission acted within its power. It will not consider the expediency or wisdom of the order, or whether, on like testimony, it would have made a similar ruling. 'The findings of the Commission are made by law prima facie true, and this court has ascribed to them the strength due to the judgments of a tribunal appointed by law and informed by experience.' Illinois C. R. Co. v. Interstate Commerce Commission . . . . Its conclusion, of course, is subject to review, but, when supported by evidence, is accepted as final; not that its decision, involving, as it does, so many and such vast public interests, can be supported by a mere scintilla of proof, but the courts will not examine the facts further than to determine whether there was substantial evidence to sustain the order." 50

So far as decisions on issues of fact are concerned, the court says that "when supported by evidence" such decisions are to be accepted as final. The court further states that the term "evidence" as so used should not be construed to mean "a mere scintilla of proof", but, on the other hand, that the courts should not examine the facts further than to determine whether there was "substantial evidence" to sustain the order. In short, the court should not weigh the testimony nor balance the persuasiveness of the offerings of one side against those of the other. Somewhere between the two extremes of weighing on the one hand and the scintilla on the other was the standard thus fixed by the court to determine the scope of judicial review of the Interstate Commerce Commission's decisions. At least the outer limits were defined. These Commerce Commission cases should be treated as having a defi- 
nite bearing upon the meaning of the phrase, "if supported by testimony," which appears in the Federal Trade Commission Act, because they were firmly in the minds of the members of the Congress when the Act was adopted.

From still another branch of the administration of justice was experience brought to bear upon the problem, namely from the trial of jury cases in law actions. Many members of Congress were members of the bar and were, of course, familiar with the general rules applicable to the direction of verdicts in jury trials and to the setting aside of such verdicts because contrary to the evidence. In connection with directing verdicts, since the "scintilla rule" had, by I9I4, been abandoned in the federal courts and in most of the state courts, verdicts were directed by trial courts at the close of the testimony whenever upon the whole record the evidence for the moving party was so persuasive that no reasonable jury should reach a conclusion in favor of the opposing party. ${ }^{51}$ With regard to setting aside verdicts because contrary to the evidence, it was well understood that both trial courts and appellate courts were obligated to do so and to order new trials whenever verdicts might have been directed under the standard above set forth. ${ }^{52}$ All of this procedural doctrine was well understood by most members of Congress. The natural conclusion for these members to reach with respect to proper standards to be prescribed regarding court review of an administrative agency's fact decisions was that such review should be approximated or perhaps equated to the review of jury verdicts and that commission decisions should be accorded a like degree of finality.

Therefore, in the Commerce Commission cases and in the rules applicable to jury trials we find illuminating historical background which is useful in probing the meaning intended by Congress to be ascribed to the substantial evidence rule. An examination of the rec-

5I. In a recent Montana Supreme Court opinion the rule concerning setting aside the verdict of a jury is interestingly though rather vaguely expressed. The case was an automobile accident case. The trial court had refused to direct the verdict and the jury had rendered a decision for the plaintiff. The question which the appellate court had to decide was whether or not a verdict should have been directed in favor of the defendant. The court in discussing the case said, "It is true that where the record presents a conflict in the evidence resolved by the jury in favor of the plaintiff the action of the jury precludes this court from disturbing the verdict . . . but this is true only when there is substantial evidence in the record to support the verdict and judgment. . . . If all reasonable men must conclude that the evidence does not establish such case then it is not substantial evidence." The court thereupon reversed the judgment and remanded the cause with direction to dismiss the action. Morton $v$. Mooney, 97 Mont. I, 33 P. (2d) 262 (1934).

52. Attention is again called to the distinction between the discretionary pozver of the trial court to set aside verdicts contrary to the evidence, and the duty to set aside verdicts that are palpably and grossly erroneous. See Begert v. Payne, 274 Fed. 784 (C. C. A. 6 th, I92I). In this article where reference is made to the setting aside of verdicts it is the mandatory rule to which reference is made. Obviously the discretionary rule is inapplicable. See note 44 supra. 
ords of the debates in Congress at the time the Federal Trade Commission Act and other acts incorporating the rule were being considered shows how these matters played their part. In the debates on the Trade Commission Act, when the discussion turned toward the provisions for scope of judicial review, again and again members of Congress referred to experiences in the Interstate Commerce cases and in the trial of actions at law before juries. ${ }^{53}$ There were advocates of broad judicial review in the nature of the orthodox chancery appeal with the trial virtually de novo. Senator Pomerene offered an amendment to pro.vide for such review, but it was defeated. ${ }^{54}$ At the other extreme, Senator Cummins was an advocate of review as restricted as possible within constitutional limitations, and he offered an amendment to that effect which also failed of passage. ${ }^{55}$ Then there were advocates of

53. The Illinois Central and Union Pacific cases were frequently referred to." After a discussion of the Union Pacific case, Senator Cummins said, "This probably is the clearest and most satisfactory expression of the law that can be found, and in my amendment I am endeavoring to make this law applicable to the orders of the proposed trade commission. I am endeavoring to limit the jurisdiction and power of the court to such matters as have been declared by the court always open to investigation and decision of a judicial tribunal no matter what Congressional action may be. . 5 I CoNg. REc. 13045 (1914). See also 5I Cong. REC. I3005, I3045-6, I3054-5 (I914)

Practices in trial of actions at law were also frequently mentioned as providing a useful analogue. See 5I CoNG. REc. 12997, I3004, I3046, 13052, I3I07 (I9I4).

54. The court review provisions in the amendment proposed by Senator Pomerene were as follows:

"If any corporation charged with obedience thereto fails or neglects to obey any such order, the said commission, . . may apply for an enforcement of such order to the district court . . and therewith transmit to the said court the original record in the proceedings, including all the testimony taken therein and the report and the order of the commission duly attested by it. Upon the filing of the record, the court shall have jurisdiction of the proceeding and of the questions determined therein and shall have power to make and to enter upon the pleadings, testimony, and proceedings such orders and decrees as may be just and equitable. On motion of the commission, and on such notice as the court shall deem reasonable, the court shall set down the cause for summary final hearing. Upon such final hearing the findings of the commission shall be prima facie evidence of the facts therein stated, but if either party shall apply to the court for leave to adduce additional evidence, and shall show to the satisfaction of the court that such additional evidence is competent and material, and that there were reasonable grounds for the failure to adduce such evidence in the proceeding before the commission, the court may allow such additional evidence to be taken before the commission or before a master appointed by the court, and to be adduced upon the hearing in such manner and upon such terms and conditions as to the court may seen just. . .." 5 I CONG. ReC. 12993 (1914).

55. Senator Cummins' amendment, in the nature of a substitute for the Pomerene amendment, contained the following court review provisions:

". . Any suit . . . to annul, suspend or set aside, in whole or in part, any such order of the commission shall be brought against the commission in a district court of the United States . . . and the procedure set forth in the Acts of Congress making appropriations to supply urgent deficiencies and insufficient appropriations for the fiscal year of I9I3 and for other purposes relating to suits brought to suspend or set aside, in whole or in part, an order of the Interstate Commerce Commission, shall apply ... if within the time so fixed in the order of the commission, the person, partnership or corporation against which the order is made shall not cease and desist from such unfair competition, and if in the meantime such order is not annulled, suspended or set aside by a court, the commission may bring a suit in equity . . to enforce the said order and jurisdiction is hereby conferred upon said court to hear and determine any such suit and to enforce obedience thereto according to law and rules applicable to suits in equity." 5I CONG. REC. I3045 (IgI4). 
the limited review more in accordance with practice in jury trials. An examination of the debates shows, rather more clearly than such debates usually reveal the facts, that the latter standard met favor with the majority of the members of Congress and that it was this standard which was designed to be given effect under the substantial evidence rule finally written into the Federal Trade Commission Act. ${ }^{56}$

Furthermore, the later enactments using the substantial evidence rule either in the language of the Trade Commission Act or in the expanded form with the word "substantial" as an adjective defining the word "evidence", were all patterned after the Trade Commission Act so far as the scope of review is concerned and are, therefore, properly deemed based upon the same legislative history and pre-legislative background. Indeed, the debates on some of these later enactments clearly so indicated.

In 1938, when the debate on Section 5 of the Federal Food and Drug Act was taking place, there was some especially illuminating discussion on the floor of the House of Representatives. The bill as passed by the Senate provided that the Secretary's regulations could be enjoined by the federal district courts, but only if "unreasonable, arbitrary, or capricious, or not in accordance with law." This was thought to be a narrow review. A House amendment ${ }^{57}$ provided for issuance of injunctions in the federal district courts. The transcript of the proceedings before the Secretary was to be filed, but the complainant had the right to adduce additional evidence before the court or a master. This amendment was deemed to open the door to full court review of the facts. ${ }^{58}$ The conference committee agreed upon a compromise measure providing for review in any circuit court of appeals and stipulating that "the findings of the Secretary as to the facts, if supported by substantial evidence, shall be conclusive." This provision finally became the law.

Congressman Lea, in reporting to the House for the conference committee, made a definite statement concerning the scope of judicial review intended under the conference compromise. His statement was followed by a brief debate on the subject, and some of the excerpts from the Congressional Record are worthy of note:

"LEA: . . as I understand it, the fundamental purpose back of court review is not that the court shall dominate an administrative agency but rather restrain its unwarranted actions. . . .

56. See 5I CoNG. REc. IIIO5-I4943 (I9I4), the debates extending over more than two months.

57. Section 701 ( $\mathrm{f}$ ).

58. H. R. REp. No. 2139, 75th Cong., 3d Sess. (1938) 12. Also see minority report, No. 2I39, Pt. 2, at I-3. Although the bill itself seemed ambiguous, both the majority and the minority of the committee agreed that the House amendment provided plenary review. 
This does not mean that the courts cannot inquire into the facts to see whether or not the agency of Congress has violated its duty; but on the other hand we do not assume to transfer to the courts the burden of the legislative function intended to be performed by the agency of Congress. - . . Here we provide that the action of the administrative agency shall be based on substantial evidence. The appellate court can determine among other things . . . (Sixth) Is there substantial evidence to support the findings of the Secretary? For this purpose the court must determine whether or not there is substantial evidence to support the findings made by the administrative agency. This goes to the question of - materiality. It goes into the question of whether or not the information furnished is essential and important. When we use that language we mean what the word 'substantial' means in the ordinary affairs of life. It must be important, material, substantial. It must answer the requirements of the act. In other words, the court is not debarred from going into the facts to ascertain if there is substantial evidence because there is evidence that is merely colorable, seeming, or merely nominal. It means an honest-to-God review by the court for the purpose of performing its function of protecting the law against the legislative or the executive departments of the governiment. . . .

Buck: There has been no judicial interpretation of what the word 'substantial' means in connection with evidence. The interpretation that the gentleman is putting on what substantial evidence is is the interpretation, then, that the conferees want to go into the RECORD for future consideration by any court if there is a matter of review involved; is that right?

LEA: I trust the language $I$ have used accurately reflects the viewpoint of the conferees. . . . When the bill was pending in the House it emphatically rejected a proposed amendment that would have made the findings of the Secretary conclusive if supported by any evidence . . . We are not presenting or requesting a definition in the technical sense, but in the sense of the ordinary acceptance of the meaning of the word 'substantial' . . . .

LEAvY: I take it the gentleman's definition of 'substantial evidence' would be evidence where a fact could be established by evidence. The fact is the thing that should be established, rather than the expression of an opinion by an expert. . . .

LEA: Of course the court has a right to review the whole testimony before it, with a view of determining whether or not there is substantial evidence.

LEAVY: We have direct evidence of the fact, and we have opinion evidence, when a man can qualify as an expert. . . .

LEA: Of course it is the fundamental or ultimate fact we are dealing with in deciding what is substantial evidence. . . .

House agrees to conference report." 59 
Congressman Lea's expression, "honest-to-God review", may not be sufficiently well accepted in legal parlance to cite in a brief, but nevertheless it is not wholly lacking in meaning.

In the light of the background which has been outlined, it seems clear that Congress intended the substantial evidence rule to mean a substantial review of the whole record and not merely a search for a scintilla or a modicum of testimony to support administrative orders without regard for countervailing testimony. ${ }^{60}$ Moreover, it seems fairly reasonable to conclude that the standards established in jury cases concerning directing and setting aside jury verdicts are sufficiently a part of the history of the legislation to justify the assertion that the substantial evidence rule may be approximated if not equated to them. In other words, under the rule the courts were intended to exercise the power to set aside administrative fact decisions if found, after an examination of the entire record, to be so contrary to the testimony and the inferences therefrom that no reasonable administrative agency acting reasonably could have reached such a result. Good faith compliance with the legislative mandate would dictate a development of judicial review along these lines.

Two remaining observations should be made in order to clarify the concept so far as possible. It should be noted that, as thus stated, the substantial evidence rule comprehends and applies not only to the basic or underlying fact conclusions reached directly from conflicting testimony, but also to the inferences and ultimate conclusions of fact to be drawn from the underlying facts. Both levels of fact determination must, under this interpretation, find substantial support in the evidence.

On the other hand, however, it should be noted that the rule does not and should not in any way relate to the exercise of discretionary powers validly conferred upon administrative agencies. Although the lines of demarkation are not always easy to draw, the exercise of discretion must be differentiated from the process of reaching conclusions of fact, and discretionary functioning must be left undisturbed by the courts. Phrased somewhat differently, the courts in reviewing administrative decisions cannot with propriety, in the guise of setting aside fact determinations because of insufficient evidence, substitute their judgment on discretionary matters for that of administrative agencies.

60. Under certain circumstances debates may be used to resolve ambiguities. The United States Supreme Court has expressed the rule as follows: "Since the language of the Act is not free from doubt in the particulars mentioned, we are justified in seeking enlightenment from reports of Congressional Committee and explanations given on the floor of the Senate and House by those in charge of the measure." Wright v. Vinton Branch Bank, 300 U. S. 440, 463 (1937) ; Richbourg Motor Co. v. United States, 28 I U. S. 528, 536 (1930) ; Duplex Printing Press Co. v. Deering, 254 U. S. 443, 475 (I92I). See Powell, Contstruction of Written Instruments, Part III (I939) I4 IND. L. J. 309, reprinted in condensed form in (I939) 25 A. B. A. J. I85. 


\section{Prevailing Judicial Interpretations of the Term "Substantial Evidence"}

Our remaining task is to explore the meaning which is being ascribed to the term "substantial evidence" in contemporary case law. Are the courts endeavoring to ascribe a definite content to it and, if so, are they ascribing the content seemingly intended by Congress in the enactment of the laws in question? The term has been interpreted by the courts on numerous occasions, particularly in more recent years during which the statutes enacted since 1930 have reached final decision.

Mention has already been made of the wide variety of positions taken by different courts under the various statutes. For example, there are some court opinions in which "substantial evidence" is construed to require the decision to be sustained if any "rational basis" can be found in the record supporting it. In Mississippi Valley Barge Co.v. United States, ${ }^{61}$ the Court, in an opinion written by Mr. Justice Cardozo, said: "The judicial function is exhausted when there is found to be a rational basis for the conclusions approved by the administrative body." 62 Again, in a number of opinions the term "substantial evidence" seems to be interpreted to permit setting aside administrative decisions only if the stage of "arbitrary action" is reached. ${ }^{63}$ On the other hand, in still other opinions, as has already been pointed out, the term has been virtually equated to weighing the testimony, this sometimes being accomplished by the indirect means of treating the fact issues as questions of law. This has been done particularly in the Federal Trade Commission cases.

The most frequent current interpretation can be illustrated by reference to certain cases dealing with judicial review of the decisions of the National Labor Relations Board, for the question has been more fully considered in those cases than in other fields. Several of the earlier-holdings of the Circuit Courts of Appeals under the Wagner Act indicated that the review formula should be so construed as to invoke substantially the equivalent of the standard applied by the courts in sustaining or overruling motions for directed verdicts and motions involving the legal duty of the courts to set aside jury verdicts (as distinguished from the discretionary power of trial courts to set aside verdicts which are contrary to the evidence). For example, the Circuit Court of Appeals for the Fifth Circuit in the Wallace Manufacturing

61. 292 U. S. 282 (I934).

62. For other cases in which a similar standard is expressed see $\pi$ (d) note 43 supra. Probably "rational basis" means about the same thing as the directed verdict rule.

63. For cases along this line see II (b) note "43 supra. "Arbitrariness" seems to connote some affirmative invidious conduct, and hence such a standard can be looked upon as a rather narrower review than the directed verdict rule. 
case, specifically said that "the test of substantiality [of the evidence] is the same as that presented on motion for a directed verdict in a trial at law." "64 Again, the same court in the Bell Oil and Gas case said that "a good rule for weighing the evidence to ascertain whether it is adequate for the purpose mentioned is to compare it with the evidence necessary to sustain a verdict of a jury on a similar issue." 65

Indeed, recent United States Supreme Court opinions have contained somewhat similar language. Chief Justice Hughes, in the Consolidated Edison case, wrote for the Court as follows:

"The Companies contend that the Court of Appeals misconceived its power to review the findings and, instead of searching the record to see if they were sustained by 'substantial' evidence, merely considered whether the record was "wholly barren of evidence to support them. We agree that the statute in providing that 'the findings of the Board as to the facts, if supported by evidence, shall be conclusive' means supported by substantial evidence. . . . Substantial evidence is more than a mere scintilla. It means such relevant evidence as a reasonable mind might accept as adequate to support a conclusion." 66

Later, during the same term of the Court, speaking through $\mathrm{Mr}$. Justice Stone, the Court again discussed the phrase in question, saying:

"But, as has often been pointed out, this, as in the case of other findings by administrative bodies, means evidence which is substantial, that is, affording a substantial basis of fact from which the fact in issue can be reasonably inferred. . . . Substantial evidence is more than a scintilla and must do more than create a suspicion of the existence of the fact to be established. . . . It must be enough to justify, if the trial were to a jury, a refusal to direct a verdict when the conclusion sought to be drawn from it is one of fact for the jury." 67

Many other opinions have voiced similar views approximating the substantial evidence rule to rules applicable to directed verdicts and new trials. ${ }^{68}$

64. National Labor Relations Board v. Wallace Mfg. Co., 95 F. (2d) 8I8 (C. $\dot{\mathrm{C}}$ A. $4^{\text {th }}, \mathrm{x} 938$ ).

65. National Labor Relations Board v. Bell Oil and Gas Co., 98 F. (2d) 406 (C. C. A. 5th, I938).

$229(1938)$.

66. Consolidated Edison Co. v. National Labor Relations Board, 305 U. S. 197,

67. National Labor Relations Board v. Columbian Enameling \& Stamping Co., 306 U. S. 292,299 (1939).

68. Magnolia Petroleum Co. v. National Labor Relations Board, II2 F. (2d) 545 (C. C. A. 5th, I940); National Labor Relations Board v. Goshen Rubber and MYfg. Co., IIo F. (2d) 432 (C. C. A. 7th, I940) ; National Labor Relations Board v. Sterling Electric Motors, Inc., 109 F. (2d) I94 (C. C. A. 9th, I940) ; National Labor Relations Board v. Asheville Hosiery Co., ro8 F. (2d) 288 (C. C. A. 4th, 1939); Appalachian Electric Power Co. v. National Labor Relations Board, 93 F. (2d) 985 (C. C. A. 4 th, I938). 
More recently, however, a somewhat different approach has seemingly been adopted in deciding, or at least a different practice has been used in writing, the opinions in certain of the cases decided by the United States Supreme Court. In these opinions the evidence on the one side is not set off against the evidence on the other to determine whether or not the administrative decision is so contrary to the evidence that it could not have been reached by a reasonable board acting reasonably. Instead, in several important decisions, the quest seems to have been for some evidence which could be called "substantial" on the one side without regard for the quantum of evidence on the other.

-Two recent Supreme Court opinions in Wagner Act cases in which this modified scintilla rule seems to have been followed illustrate this trend. The two cases are National Labor Relations Board v. Waterman Steamship Corporation ${ }^{69}$ and National Labor Relations Board v. Bradford Dyeing Association. ${ }^{70}$ In each of these cases, the Court, in writing its opinion, simply recounted certain features of the evidence in support of the decision of the Labor Board, and in each it reached the conclusion that "substantial evidence" was present. So far as appears from the opinion, no attempt was made to explore and analyze the remainder of the record to determine if the opposing testimony was such that a reasonable board acting reasonably could not have decided as it did, nor to inquire whether under like circumstances a jury verdict would have to be directed for the opposing party, or set aside if it ran against him. Of course, this process may have taken place in actually deciding the cases, but it is not recorded in the opinions. ${ }^{71}$

In the Waterman Steamship Corporation case, the Court, after reciting various items of testimony in support of the order of the Board, simply concluded as follows:

"From all this evidence there can be no doubt of the substantial support for the Board's finding that the crews, O'Connor, and Pelletier all lost their jobs because of C. I. O. affiliation and activities. . . . All of this is not to say that much of what has been related was uncontradicted and undenied by evidence offered by the company and by the testimony of its officers. We have only delineated from this record of more than five hundred pages the basis of our conclusion that all of the Board's findings, far from resting on mere suspicion, are supported by evidence which is substantial." 72

69. 309 U. S. 206 (1940).

70. 310 U. S. 318 (1940).

7r. There are at least two other judicial dceisions which seem to adopt the approach of the Waterman Steamship Co. and the Bradford Dyeing Ass'n cases. They are Swayne \& Hoyt, Itd. v. United States, 300 U. S. 297 (I937) ; Booth Steamship Co. v. United States, 29 F. Supp. 221 (S. D. N. Y. I939).

- 72. National Labor Relations Board v. Waterman Steamship Co., 309 U. S. 206, 224, 226 (1940). 
Moreover, in the Bradford Dyeing Association case, the Court may have intended to go even further in according finality to the fact decision of the Board, although the language used is not free from ambiguity. The Court indicated that the requirement of substantial evidence was applicable only to the determination of the underlying facts upon which the decision was based. As to the ultimate conclusions of fact to be drawn from the underlying facts, the Court indicated that, having accepted the underlying findings as made by the Board, the Court could go no further in reviewing the decision. It was said to be entirely within the province of the Board to draw the inferences necessary to reach the ultimate conclusions of fact, and the Court indicated that it had no power to enter into an inquiry concerning the reasonableness of the inferences thus drawn. This seems to depart even further from the standards of jury practice. In that area, the conclusions of fact, as well as the underlying evidentiary facts, must be properly supported by the testimony in order to prevail against a motion for directed verdict or a motion for new trial based upon insufficiency of the evidence. If inferences must be drawn to reach the ultimate conclusions of fact, they must be reasonable. If the statement in the Bradford Dyeing case becomes accepted practice, it will mark a radical departure from the original scope of the term "substantial evidence". ${ }^{73}$

Possibly the language in these recent cases is fortuitous rather than indicative of a trend in establishing a new definition of substantial evidence. Everything considered, the interpretation of the earlier cases seems the wiser. It affords a broad range of conclusiveness to administrative agencies without opening the door to gross error and injustice.

\section{Conclusions}

From the foregoing discussion the following conclusions are indicated:

(I) A reasonable adherence to the intent of Congress in using "substantial evidence" as the measure of the courts' power in proceed-

73. Certain other expressions in recent opinions indicate that the inferences to be drawn from the underlying facts may be left conclusively to the Board. $C f$. Mr. Justice Black's dissenting opinion in National Labor Relations Board v. Columbian Enameling and Stamping Co., 306 U. S. 292, 300 (1939), and possibly aiso the Court's opinion written by Mr. Justice Stone in National Labor Relations Board v. Pennsylvania Greyhound Lines, 303 U. S. 26I (I938). On the other hand in the court's opinion written by Mr. Justice Stone in the Columbian Enameling case at 299, the following statement appears, "Section Io (e) of the Act provides:. .9 The findings of the Board as to the facts, if supported by evidence, shall be conclusive'. But as has often been pointed out, this, as in the case of other findings by administrative bodies, means evidence which is substantial, that is, affording a substantial basis of fact from which the fact in issue can be reasonably inferred."

Note that the inference must be "reasonably inferred". Judging by these recent expressions of the Court there seems to be considerable uncertainty on the matter of inferences, and on the question of the authority of the Court in reviewing inferences drawn by the Board. 
ings to review administrative fact decisions requires much more than a scintilla of testimony to support such decisions and much more than a selection of testimony from one side, disregarding the testimony of the opposition. At the same time, it requires much less than a weighing of the evidence.

(2) There is ample ground to believe that Congress intended by the substantial evidence rule that the courts should survey the entire record and sustain the administrative fact decision if the evidence, including inferences therefrom, is found to be such that a reasonable man acting reasonably might have reached the decision. On the other hand, if a reasonable man acting reasonably could not have reached the decision upon the evidence and the inferences therefrom, then the decision is not supported by "substantial evidence" and it should be set aside.

(3) Thus conceived, judicial review is approximated or perhaps even equated to the rules concerning motions for directed verdicts and to the rules placing courts under a duty to sustain motions for new trials in jury cases. There is merit in attaining this approximation. Such a standard will neither hamper administrative efficiency nor overload the courts. Jury verdicts are only infrequently set aside, but there is always the safeguard against gross error. On the other hand, there is definite gain from simplification of concepts and from taking advantage of the familiarity derived from related fields of procedure.

(4) Thus conceived and interpreted, the substantial evidence rule is eminently sound, provided always that it is limited to fact questions and not extended into the domain of legitimate administrative discretion, and provided, further, that the courts in passing upon what the reasonable man would or would not decide take due account of the element of technical expertness found to exist in the administrative arena.

Though "substantial evidence" may not thus be made "a crystal, transparent and unchanging," at least it is given a considerable measure of body and substance as the "skin of a living thought." 